\title{
HEARING SCREENING OF INFANTS IN NEONATAL UNIT, HOSPITAL UNIVERSITI SAINS MALAYSIA USING TRANSIENT EVOKED OTOACOUSTIC EMISSIONS
}

\author{
By
}

\author{
DR. MOHD KHAIRI BIN MD. DAUD \\ MD (USM)
}

\author{
A dissertation submitted in \\ partial fulfilment of the \\ requirements for the degree of \\ Master Of Medicine \\ (Otorhinolaryngology - Head \& Neck Surgery)
}

November 2001 


\section{ACKNOWLEDGEMENT}

My sincere thanks and gratitude to Associate Professor $\mathrm{Hj}$. Dinsuhaimi bin Sidek for his consistent monitoring and precious suggestions in conducting this study. I am also indebted to Dr Lin Naing @ Mohd Ayub Sadiq (lecturer in Community Medicine), and Dr Normastura for their help in statistical analysis. My appreciations for Dr Nik Zainal, the Head of Paediatric Department and Neonatal Unit staffs for their cooperation at the time of examination. Not the least, the audiology staffs who have help me during the follow up of the patients and deserved recognition.

My wife's (Dr Normastura) help has taken diverse form - statistical analysis, technical, clerical and critical. She deserve my admiration and she has my sincere thanks, and so do Nur Ain Ayuni, Muhammad Afiq and Nur Ain Athirah, who have lost a little of their childhood along the way. 


\section{TABLE OF CONTENTS}

TITLE

page

Acknowledgement

ii

Table of contents

iii

List of tables

vi

List of figures

vii

Abstract

viii

Abstrak

$\mathbf{x}$

Chapter 1. Introduction 1

1.1 Epidemiology 1

1.2 Development Of The Human Central Auditory System $3 \quad 3$

1.3 Speech Perception 5

1.4 Etiology Of Hearing Loss In Children 6

1.4.1 Hereditary Hearing Impairment 7

1.4.1(a) Autosomal Recessive Syndromes $\quad 7$

1.4.1(b) Autosomal Dominant Syndromes $\quad 8$

1.4.1(c) X-Linked Recessive Syndromes 9

1.4.1(d) Mitochondrial Syndromes 9

$\begin{array}{ll}\text { 1.4.2 Hypoxia } & 9\end{array}$

1.4.3 Persistent pulmonary extracorporeal membrane oxygenation 10 
1.4.4 Hyperbilirubinaemia

1.4.5 Ototoxic medications

1.4.6 Meningitis

1.4.7 Congenital infections

1.4.7(a) Cytomegalovirus

1.4.7(b) Herpes Simplex infection

1.4.7(c) Congenital Rubella

1.4.7(d) Congenital Syphylis

1.4.7(e) Congenital Toxoplasmosis

1.4.8 Noise-induced hearing loss

1.4.9 Hypothyroidism

1.5 Screening

1.6 The need for an early hearing screening

1.7 Limitations of current methods

1.8 History of infant hearing screening

1.9 Hearing screening in Malaysia

1.10 Otoacoustic emission: an emerging clinical tool for hearing screening

1.11 Factors affecting the transient evoked otoacoustic emission screen results (The Rhode Island Hearing Assessment Program Experience) 
CHAPTER 2. AIM OF STUDY AND RESEARCH HYPOTHESIS

2.1 Rationale

2.2 Objective

2.3 Research Questions / Hypothesis

CHAPTER 3. MATERIALS AND METHOD

3.1. Research Methodology

3.2. Study Instruments

3.3. Study Procedure

3.4. Data entry and analysis

CHAPTER 4. RESULTS

CHAPTER 5. DISSCUSSION

CHAPTER 6. CONCLUSION

CHAPTER 7. RECOMMENDATIONS

APPENDIX B FORMAL LETTER TO THE HEAD OF PAEDIATRIC 
APPENDIX C JOINT COMMITTEE ON INFANT HEARING 1994 POSITION STATEMENT (HIGH RISK CRITERIA)

APPENDIXD ECHOCHECK 


\section{LIST OF TABLES}

$\begin{array}{ll}\text { TABLE PAGE } & \text { PA }\end{array}$

Table 1: Association between high risk infants with hearing impaired. 48

Table 2:Univariate analysis of risk factors associated with hearing impairment.

Table 3: Association between ototoxic medication with hearing impairment.

Table 4: Association between stigmata / syndromal with hearing impairment.

Table 5: Clinical synopsis of 5 neonates with hearing impairment

Table 6: Estimated costs of operating a newborn screening program.

Table 7: Background noise in the neonatal unit 


\section{LIST OF FIGURES}

FIGURE

PAGE

Figure 1: Ethnic distribution of infants $\quad 40$

Figure 2: Sex distribution of infants screened 41

Figure 3: Histogram of birth weight 42

Figure 4: Histogram of age at test 43

Figure 5: Risk factors in 401 infants.

Figure 6: Number of risk factors per child. $\quad 46$

Figure 7: Flow diagram of neonatal hearing screening and outcome. $\quad 47$

Figure 8 : Duration of testing each infants. 51 


\section{ABSTRAK}

Objektif: Kajian prospektif ini melaporkan prevalen kecacatan pendengaran di kalangan pesakit yang menerima rawatan di dalam Unit Neonatal (bayi yang telah menerima rawatan di unit rawatan rapi dan yang menghadapi masalah kurang serius). Rekabentuk kajian: Dari 15hb. Februari hingga 15hb. Mac, 2000 dan dari $15 \mathrm{hb}$. Februari hingga 15hb. Mei, 2001, seramai 401 orang bayi telah menjalani ujian saringan pendengaran dengan menggunakan "transient evoked otoacustic emissions" diikuti ujian saringan kedua untuk bayi-bayi yang gagal di dalam ujian pertama. Keputusan: $370(92.27 \%)$ orang bayi telah lulus saringan pertama untuk kedua-dua belah telinga. Lapan (2\%) orang bayi telah gagal untuk sebelah telinga manakala $23(5.74 \%)$ orang bayi telah gagal untuk keduadua belah telinga, menjadikan sejumlah $7.74 \%$ daripada bayi-bayi tersebut dicadangkan untuk menjalani ujian saringan kedua. Seramai lima daripada dua puluh satu orang bayi yang telah hadir untuk saringan kedua telah gagal di dalam ujian tersebut menjadikan prevalen kecacatan pendengaran sebanyak $1.28 \%$. Kecacatan kepala dan muka, berat lahir yang sangat rendah, penggunaan ubat "ototoxic", stigma/sindrom yang berkaitan dengan kecacatan pendengaran dan "hyperbilirubinaemia" pada tahap yang memerlukan pertukaran darah telah dikenalpasti sebagai factor-faktor risiko untuk kecacatan pendengaran. Purata masa yang diambil untuk satu-satu ujian ialah 5.43 minit. "Apgar score" yang rendah dan ventilasi mekanikal melebihi 5 hari telah didapati tidak berkaitan dengan kecacatan pendengaran di dalam kajian ini. 


\section{ABSTRACT}

Objective: this prospective study reports on the prevalence of hearing impairment in neonatal unit population (NICU graduates and less severe ill infants). Design: from $15^{\text {th }}$ February, 2000 to $15^{\text {th }}$ March, 2000 and $15^{\text {th }}$ February, 2001 to $15^{\text {th }}$ May, 2001, 401 neonates were screened with transient evoked otoacoustic emissions (TEOAE) followed by second stage screening of the infants who had failed the initial test. Results: 370 (92.27\%) infants passed the primary screen for both ears. Eight $(2 \%)$ infants failed one ear and twenty three $(5.74 \%)$ infants failed both ear, adding up to $7.74 \%$ planned for second stage screening. Five out of twenty two infants who had come for the follow up failed the screening resulting the prevalence of hearing impairment of $1.28 \%$. Craniofacial malformations, very low birth weight, ototoxic medication, stigmata / syndromes associated with hearing loss and hyperbilirubinaemia at the level of exchange tranfusion were identified to be independent significant risk factors for hearing impairment. The mean total test time was 5.43 minutes. Poor apgar score and mechanical ventilation of more than 5 days were not found to be associated with hearing impairment in the present study population. Conclusion: Hearing screening in high-risk neonates revealed a total of $1.28 \%$ with hearing loss. Significant risk factors were craniofacial malformations, very low birth weight, ototoxic medication, stigmata / syndromes associated with hearing loss 
and hyperbilirubinaemia at the level of exchange tranfusion. Other perinatal complications did not significantly influence screening results indicating improved perinatal handling in a neonatal population at risk for hearing disorders. 
CHAPTER 1

INTRODUCTION 


\section{CHAPTER 1}

\section{INTRODUCTION}

The proverb says, "As we hear, so shall we speak." It is this intimate relationship between speech, language and hearing that has fascinated man since the beginning of time. Many believe that language is inherent in each child's maturation, needing only the appropriate environment to trigger the process. Speech and language are naturally and easily acquired by most children. However, the child with hearing loss does not automatically develop speech and may be confronted with a life of language difficulties and educational struggles. Because hearing loss in infants typically is a silent and hidden handicap, identification and treatment of the problem is often delayed. Undetected hearing loss can lead to delayed or impaired speech and language development, social and emotional problems, underachievement and academic failure.

\subsection{Epidemiology}

Significant hearing loss is one of the most common major abnormalities present at birth. It is the most common birth defect in America today (Sorensen, 1998). Hearing impairment ranging from mild to profound. Even mild hearing impairment seriously affects language, speech and cognitive development (Yoshinaga-Itano, 1998). Early identification and intervention lead to improved 
communication skills, which positively impact psychosocial, educational and vocational development.

Permanent hearing impairment occurs with a prevalence of about one to three per 1000 live births (Watkin, 1995, Finitzo et al., 1998, Mason and Hermann, 1998, Vohr et al., 1998, Watkin and Baldwin, 1999). The occurrence of hearing loss is considerable greater in certain sub-populations, ranging from 1 to 5 in 100 in neonatal intensive care populations and groups of infants selected by current at-risk registers (Shannon et al., 1984, Watkin et al., 1991, Watson et al., 1996, Hess et al., 1998, Mason et al., 1998, Meyer Jan et al., 1999). Studies indicate that screening by high risk registry alone leads to the identification of at best only 50-75 percent of infants with hearing loss (Watkin et al., 1991, Hess et al., 1998, Sorensen, 1998, Task Force on Newborn and Infant Hearing, 1999).

About half of all moderate to profound permanent bilateral hearing loss present at birth or occurring in early childhood is associated with genetic factors; one third occurring in syndromic form. Dominant inheritance accounts for about $10 \%$; recessive inheritance for up to $40 \%$; and sex-linked patterns 1 $2 \%$. Another $10-20 \%$ occurs as a result of congenital infection, with some $10-$ $15 \%$ a by-product of prematurity or a perinatal complication, such as asphyxia, elevated bilirubin or respiratory distress. The remaining $30 \%$ of all hearing loss present in early childhood has no obvious cause.

As far as the author may concern, there is no published study either internationally or locally regarding the prevalence of hearing loss in Malaysia. However, there was a study done by Ass. Prof. Dr Din Suhaimi to determine the high risk factors for deafness of children in Kelantan. He found that $14.7 \%$ of the 
patients had family history of hearing loss, $6.7 \%$ had been ventilated for more than 10 days, $4.0 \%$ had received ototoxic medications for more than 5 days, $2.7 \%$ each for the patients who has malformation in the head and neck region, birth weight less than $1.5 \mathrm{~kg}$, hyperbilirubinaemia and with history of bacterial meningitis, $1.3 \%$ has congenital infection and the remaining $62.5 \%$ has no obvious cause.

\subsection{Development Of The Human Central Auditory System}

The inner ear is nearly fully developed at birth, and the brain stem develops during the perinatal period and becomes fully mature within the first 2 or 3 years of life (Roizen \& Dieffendorf, 1999, Garganta \& Seashore, 2000). Cortical development is somewhat delayed, but with the exception of its commissural connections, the human auditory cortex also reaches a stage of relative maturity by age 2 or 3 years.

Although the primordial of auditory centres are identifiable by the third to eight prenatal weeks, the first signs of expansion of the brain stem auditory pathway occur at the $16^{\text {th }}$ to $20^{\text {th }}$ weeks of gestation, when neurons develop visible cytoplasm, and neurofilament-containing axons proliferate in the auditory nerve, trapezoid body and lateral lemniscus. During the $24^{\text {th }}$ to $26^{\text {th }}$ gestational weeks, these axons undergo terminal branching within their target nuclei, and the first short dendrites appear on neurons in the cochlear, olivary, and collicular nuclei. The coincidental development of axon terminals and dendritic processes probably reflects the first appearance of synapses, preparatory for the onset of function, at around the $28^{\text {th }}$ gestational week. The onset of 
synchronized conduction at this time is signalled by the simultaneous appearance of acousticomotor reflexes, recordable ABRs and myelin in the auditory nerve and brain stem pathways. During the 3 months between onset of transmission and term birth, increased myelin density is reflected in rapidly increasing conduction velocity in auditory pathways. The result of this rapid maturation is that axonal conduction time through the brain stem reaches the adult value by the time of term birth; synaptic transmission time lags somewhat behind axonal transmission, but the latency of impulses crossing synaptic points in the cochlear nuclei and olivary nuclei is adult-like by age 1 or 2 years.

Auditory cortex maturation occurs later than that of the brain stem in that, at term, it is only half of its adult thickness, and its laminar pattern of cytoarchitecture is indistinct. At approximately the fourth postnatal month, neurofilament-containing axons begin to sweep into the cortex in parallel arrays and penetrate layers 4, 5, and 6. Myelination of afferent and efferent axons in these deeper layers occurs at approximately 11 months of age, coincident with the onset of speech production, but axonal density continues to increase until 2 or 3 years of age. Layers 2 and 3 , which are the source and terminus of commissural axons passing through the corpus callosum, remain only sparsely filled with mature axons until several years later, when interhemispheric sensory transfer begins to mature.

In summary, development in the brain stem auditory pathway parallels that of the inner ear in that both begin to function several months before birth. This preparation for immediate function allows newborns to process sounds and accurately analyse their loudness and pitch. It also underlies infant's ability to carry out tasks that involve central neural processing, such as integration of 
input to the two ears to localize a sound source or discrimination of specific speech sounds. The shift in perceptual ability that occurs in infants in the second half of the first year of life, with a preference for the sounds and patterns of their native language, probably reflects the beginning of cortical maturation and its influence on the perceptual process.

\subsection{Speech Perception}

The ability of human neonates to hear, remember, and discriminate speech sounds has been demonstrated in studies using differential cardiac response, sucking rate, or conditioned head turning to familiar versus novel sounds. Soon after birth, human infants show a greater response to vowels than to tones or noise and remember previously heard speech sounds for at least 24 hours. At 2 or 3 months of age, speech sounds such as consonant pairs, are discriminated across the same boundaries as are used by adults. In the first month life, infants detect changes in word order in sentences and retain more information about two-syllable phrases that share an initial consonant and vowel.

Changes that suggest that infants are beginning to learn about the organization of sound patterns in their native language occur in the second half of the first year of life. One to four-month-old infants make speech syllable contrasts equally well in their parental language. By 6 months of age, infant can accurately categorize variants of vowels that appear in the language to which they have been exposed. This demonstrates the effects of very early experience on developing speech perception ability and provides evidence that very young infants process speech and form important neural connections long 
before it is apparent. Speech perception development continues into childhood, but the ability to alter speech sound categories with experience falls off dramatically with age.

\subsection{Aetiology Of Hearing Loss In Children}

The frequency of the various causes of hearing loss in children has changed over the past 30 years and will probably continue to change as newborn hearing screening becomes available to all children and as we develop more ways to prevent hearing loss. The greatest victories in the arena of prevention of hearing loss in children have been in the infectious diseases. Congenital rubella has become almost nonexistent in the United States with the introduction of the vaccine. With the introduction of the Haemophilus influenza $B$ vaccine, the bacterial meningitis that has been responsible for most meningitis-induced hearing loss has been enormously decreased. These advances have resulted in hereditary causes and neonatal intensive care unit (NICU) graduates contributing most children with hearing loss.

As mentioned before, most report assign approximately $50 \%$ of childhood hearing impairment to genetic factors; $20 \%$ to $30 \%$ to prenatal, perinatal, or postnatal environmental causes; and $25 \%$ to $30 \%$ to uncertain causes. 


\subsubsection{Hereditary Hearing Impairment (HHI)}

Approximately $80 \%$ of $\mathrm{HHI}$ is inherited as an autosomal recessive trait, $18 \%$ autosomal dominant, and approximately $2 \%$ X-linked recessive (Tomaski \& Grundfast, 1999). Rarely, HHI can be inherited as a result of a defect in the mitochondrial rather than nuclear DNA. The total number of genes that can cause all types of $\mathrm{HHI}$ has been estimated to be approximately 200 (Tomaski \& Grundfast, 1999), and significant progress is being made in locating the involved genes.

Genetic hearing loss may exist with associated anomalies (syndromic hearing loss) or be present alone (isolated hearing loss without associated findings). Two thirds of cases of $\mathrm{HHI}$ are nonsyndromic, whereas one third of cases of $\mathrm{HHI}$ have associated clinical symptoms. Thus, more children have hereditary deafness that has no associated findings with the deafness. During the past few years, mutations of multiple genes have been identified that result in nonsyndromic hearing loss. They include 16 autosomal dominant forms (designated DFNA1-DFNA17), 25 autosomal recessive forms (DFNB1DFNB25)(Green et al., 1999), and 4 X-linked forms (DFN1-DFN6)(Garganta \& Seashore, 2000). Knowledge of these genes and the mutations that result in hearing loss often allows genetic testing of a hearing impaired child.

\subsection{1(a) Autosomal Recessive Syndromes}

Recessively inherited hearing impairment accounts for approximately $80 \%$ of HHI (Tomaski and Grundfast, 1999), which means that most children with HHI may not have affected relatives in previous generations. For this type of 
inheritance to occur, the affected individual must have inherited two abnormal genes, one from each parent. Thus, these children often are the offspring of parents without any sign of hearing impairment who carriers of a single recessive gene for hearing impairment. Mutations in the gene for connexin-26 (gap junction protein B2, [GJB2] gene) are thought to be responsible for half of the severe-to-profound autosomal recessive nonsyndromic hearing loss. Green et al. (1999) found that $3 \%$ of the general population in the Midwestem United States earned mutations in this gene and that $2.5 \%$ of the population carried the most common mutation, $35 \mathrm{delG}$. They also found that $42 \%$ of hearing-impaired children without a family history of hearing loss had mutations in connexin-26. In another study, Estivill et al. (1998) found that $37 \%$ had mutations in the gene.

The syndromic group include Usher Syndrome, Pendred Symdrome, Jervell and Lange-Nielsen Syndrome and Branchio-Otorenal Syndrome.

\subsection{1(b) Autosomal Dominant Syndromes}

The syndromic group include Alport Syndrome, Mandibulofacial Dysostosis (Treacher-Collins) Syndrome, Neurofibromatosis, Stickler Syndrome (MarshallStickler Syndrome, Hereditary Arthro-Ophthalmolopathy) and Waardenburg Syndrome Syndrome. Nonsyndromic autosomal dominant delayed-onset progressive sensorineural deafness is a relatively common type of hearing impairment. The hearing loss usually begins in the second or third decade and can progress to profound deafness involving both ears. Two genes causing dominant progressive hearing impairment have been located, one on chromosome 1p and one on chromosome 5q (Mhatre \& Lalwani, 1996). Another form is dominant early-onset progressive sensorineural hearing loss. Usually, 
affected individuals develop high-frequency sensorineural hearing loss during the first decade of life, and hearing impairment progresses to more frequencies with increasing age.

\subsection{1(c) X-Linked Recessive Syndromes}

$\mathrm{X}$-linked refers to genes found on the $\mathrm{X}$ chromosome. Most $\mathrm{X}$-linked hearing loss genes are recessive. Females with an $\mathrm{X}$-linked hearing loss gene most likely have a dominant gene for hearing on their second $X$ chromosome and are therefore carriers. A carrier has a $50 \%$ chance of passing on the hearing loss gene. If a boy receives the hearing loss gene, he will manifest the hearing loss. $X$-linked congenital sensorineural hearing loss and X-linked hearing loss with stapes fixation and perilymphatic gusher are included in this group.

\subsection{1(d) Mitochondrial Syndromes}

Mitochondrial inheritance contributes less than $1 \%$ of all HHI. Transmission occurs from affected females. Abnormalities of mitochondrial DNA can produce either an isolated hearing loss or a hearing loss associated with other features of mitochondrial disorders. These include lactic acidosis, encephalopathy, myopathy, seizure disorder, ophthalmoplegia, diabetes mellitus, cardiomyopathy, strokelike episodes, ataxia, and optic atrophy.

\subsubsection{Hypoxia}

Most studies of the cause of hearing loss in NICU graduates have identified hypoxia to be a factor. In different studies, hypoxia has been defined differently. 
Hypoxia may be defined as apnoea, a difficult delivery, a history of duration of ventilation, a lower Apgar score at 5 minutes, or documented Po2 of less than $50 \mathrm{~mm} \mathrm{Hg}$ (Roizen, 1999). Bergman et al. (1985) identified 36 children with a sensorineural hearing loss of less than $55 \mathrm{~dB}$ bilaterally in their NICU follow-up program, which included all infants of less than $1500 \mathrm{~g}$ birth weight or with neonatal seizures. One of the significant neonatal predictors of hearing loss in high-risk premature infants was prolonged respirator care $(p=0.0004)$. Salamy et al. (1989) studied prospectively 12 infants with sensorineural hearing loss from a group of 224 very low birth weight $(<=1500 \mathrm{~g})$ infants requiring NICU care. They found that the infants with hearing loss had a Po2 less than $50 \mathrm{~mm}$ $\mathrm{Hg}$ more frequently than the control infants $(p<0.01)$. However, the precise pathophysiologic mechanism responsible for the SNHL is not clear in all cases (Brookhouser, 1996).

\subsubsection{Persistent Pulmonary Hypertension and Extracorporeal Membrane}

\section{Oxygenation}

Persistent pulmonary hypertension or persistent fetal circulation occurs as a result of failure of the circulatory adaptation at birth with the high pulmonary vascular resistance in utero continuing and causing right-to-left shunting at the levels of both of the foramen ovale and ductus arteriosus. Persistent pulmonary hypertension, primarily a disorder of full-term infants, is manifested by continued severe hypoxaemia despite conventional ventilatory management. Management of infants with the disorder includes hyperventilation and/or the use of pulmonary vasodilators such as tolazaline. Hendricks-Munoz et al. (1988) found 
that the incidence of hearing loss for infants with persistent pulmonary hypertension is $52.5 \%$ if the infants with assumed normal hearing are excluded. Nevertheless, they speculated that the increased observation of hearing loss with the disorder might be due to aggressive hyperventilation associated with diuretic therapy. (15) However, Marron et al. (1992)(16) in their follow-up study of 27 children with PPHN found none to have SNHL.

Extracorporeal membrane oxygenation (ECMO) is a complex technique for providing life support in respiratory failure. This technique oxygenates blood outside the body, obviating the need for gas exchange in the lungs, and if necessary, provides cardiovascular support (UK Collaborative ECMO Trial Group, 1996). Kawashiro et al. (1996) found that 8 of 10 children who developed hearing loss after discharge from the NICU had PPHN, and 6 of the 8 had required ECMO. Desai et al. (1997) found SNHL in $12(15 \%)$ of 80 ECMO-treated children.

\subsubsection{Hyperbilirubinemia}

Elevated serum bilirubin during the neonatal period, sufficient to permit passage through the blood-brain barrier, can result in deposits in the basal ganglia, including the ventrocochlear nucleus, leading to neurologic sequelae (Brookhouser, 1996). In the presence of hyperbilirubinaemia, specific aberrations appear in brain stem responses (ABRs). These aberrations disappear after exchange transfusion and the establishment of a normal bilirubin level (Perlman et al., 1983). De Vries et al. (1985) studied the relationship of serum bilirubin level to ototoxicuty and deafness. They found that 
the mean duration of hyperbilirubinaemia was significantly longer in the deaf infants $(p<0.02)$. They also concluded that in healthy preterm infants with birth weight greater than $1,500 \mathrm{~g}$, high bilirubin levels carry little risk, whereas a serum bilirubin level greater than $240 \mu \mathrm{mol} / L$ in high risk preterm infant with birth weight of $1,500 \mathrm{~g}$ or less is associated with a high risk of deafness. In a study of 56 children of less than $1000 \mathrm{~g}$ birth weight, Doyle et al. (1992) found that all of the four children with SNHL had significantly higher maximum concentrations of bilirubin in the newborn period (median $167 \mu \mathrm{mol} / \mathrm{L}$ vs 138 $\mu \mathrm{mol} / \mathrm{L})$. Bergman et al. (1985), in their study of a group of NICU graduates with a birth weight of up to $1500 \mathrm{~g}$ or neonatal seizures found that maximum serum bilirubin levels were one of several independent predictors of hearing loss $(p=$ 0.0057 ) and that a negative correlation was found with the number of exchange transfusions $(p=0.0207)$.

\subsubsection{Ototoxic medications}

Aminoglycoside antibiotics are known to cause sensorineural hearing loss in adults, especially in the presence of renal impairment, concomitant use of diuretics, or prior use of other aminoglycosides. To what extent these drugs are associated with ototoxicity in newborn infants is unclear. A divergent view is that the newborn infant, especially the preterm infant, is at greatest risk for ototoxicity because of renal immaturity and the presence of multiple organ system disease that may act singly or synergistically with aminoglycosides to damage the inner ear. 
Using ABR, Bernard (1985) reported a larger incidence of hearing loss in 26 premature infants given gentamicin or tobramycin than in an age-matched nontreated control group. However, several other studies of the factors associated with SNHL in NICU graduates have not found the use of aminoglycosides in the NICU to be a significant predictor of SNHL (Bergman, 1985, Finitzo-Hieber, 1985, Salamy, 1989, Hess et al., 1998, Meyer Jan et al., 1999).

Studies of frusemide in the neonatal period, especially with greater amounts of administration for longer durations and in combination with aminoglycosides, are associated with an increased risk for hearing loss (Salamy, 1989).

\subsubsection{Meningitis}

Bacterial meningitis has been the leading cause of acquired SNHL in children. Serial recordings of BAEP beginning within 48 hours of admission have shown the early occurrence of hearing loss, with a possible recovery or worsening occurring during the first 2 weeks with no cases of "late" deafness or "late" recovery (Kaplan et al., 1984, Vienny et al., 1984). Clinical and experimental research indicates that the hearing loss after meningitis is caused by cochlear damage by ototoxic drugs used to treat the meningitis or to direct damage to the cochlea by the meningitis (Francois et al., 1997). In a study of 432 children with meningitis, Woolley (1999) found that $59(13.7 \%)$ had the development of hearing loss. Of these 59 children, $46(78.0 \%)$ had stable sensorineural hearing loss and $13(22.0 \%)$ had either progressive or fluctuating hearing loss. Streptococcus pneumonia appears to be the most virulent in 
causing hearing loss, with $23.8 \%$ of the children having pneumococcal meningitis in this study so affected. In another study, Dodge (1984) found that overall $10.3 \%$ of the patients had persistent bilateral or unilateral SNHL, with Streptococcus pneumoniae having the highest incidence $(31 \%)$, followed by Neisseria meningitidis $(10.5 \%)$ and $H$. influenzae $(6 \%)$. In one study of 80 children with meningitis caused by $\mathrm{N}$. meningitidis, $9 \%$ developed SNHL (Edwards et al., 1981). S. pneumoniae not only has had the highest frequencies of SNHL but also has high mortality rates and neurologic morbidity (Wald et al., 1986). Little is reported about hearing loss in children with fungal infections, but one study reported 3 children out of 7 children with fungal meningitis developed SNHL (Roizen, 1999). There have been no studies of the sequelae of viral meningitis that have reported SNHL (Wilfert et al., 1981).

\subsubsection{Congenital Infections}

\subsection{7(a) Cytomegalovirus}

Cytomegalovirus infection occurs in $0.2 \%$ to $2.2 \%$ of all newborns, making it the most common intrauterine infection in humans (Roizen, 1999). Ramsay (1991) found that up to $10 \%$ of children with congenital CMV infection exhibit systemic and neurologic symptoms at birth, and $61 \%$ of these children develop SNHL. Fowler (1997) prospectively evaluated 307 children with documented asymptomatic congenital CMV infection and found that $22(7.2 \%)$ had SHNL. Among the children with hearing loss, further deterioration of hearing occurred in $50.0 \%$, with the median age at first progression at 18 months. Delayed-onset SNHL was observed in $18.2 \%$ of the children, with the median age of detection 
at 27 months. Fluctuating SNHL was documented in $22.7 \%$ of the children with hearing loss. Eleven of the children had unilateral losses, and 12 of the ears had a severe to profound hearing loss. The authors speculated that more children with asymptomatic CMV would probably develop late-onset hearing loss and recommend that children with congenital CMV have continued monitoring of their hearing status.

\subsection{7(b) Herpes Simplex Infection}

Neonatal herpes simplex virus (HSV) infection is a rare but potentially fatal disease that occurs in 1 in 2500 to 1 in 10,000 pregnancies. In one study, the neurologic impairment, including hearing loss, is found in most children with the disseminated presentation, $40 \%$ of the children with encephalitic presentation, and $25 \%$ of children with infection confined to the skin, mouth or eyes (Roizen, 1999).

\subsection{7(c) Congenital Rubella}

Hearing loss is the most common permanent manifestation and affects $68 \%$ to $93 \%$ of children with congenital rubella (Roizen, 1999). Das (1996) found that 18 out of 339 patients with SNHL have congenital rubella. However, since the introduction of the rubella vaccine, the number of congenital rubella cases continues to decrease.

\subsection{7(d) Congenital Syphilis}

Hearing loss is one of the late manifestations of syphilis and occurs after 2 years of age. The hearing loss results from persistent, active disease with 
ongoing inflammation and scarring. Prevalence estimates for SNHL range from $3 \%$ to $38 \%$, with more than one third of these patients becoming symptomatic prior to age 10 years (Brookhouser, 1996).

\subsection{7(e) Congenital Toxoplasmosis}

In one study, they found that $10 \%$ to $15 \%$ of children with congenital toxoplasmosis developed educationally significant hearing loss (Roizen, 1999). In a group of 30 children who had been treated at birth with pyrimethamine and sulfonamide, they reported no development of hearing loss.

\subsubsection{Noise-Induced Hearing Loss}

The evidence that fetuses and newborns exposed to excessive noise may suffer SNHL is unclear. In one study, children with high-frequency hearing loss tested at 4 to 10 years of age were more likely to have been born to women who were exposed consistently to occupational noise in the range of 85 to 95 dB during pregnancy (Committee on Environmental Health, 1997). Other studies have been inconsistent in relation to exposure to excessive noise (Roizen, 1999).

Many studies have documented the continuous noise exposure associated with NICUs varies from $60 \mathrm{~dB}$ to $80 \mathrm{~dB}$ (Brookhouser, 1992), with intense short duration noise from such things as the closing of the metal cabinet doors (90 $\mathrm{dB}$ ) and dropping the head of the mattress (120 dB) (Committee on Environmental Health, 1997). Many studies have documented hearing loss in children cared for in NICU (Bergman et al, 1985). 


\subsubsection{Hypothyroidism}

Rovet (1997) retrospectively studied 101 children followed longitudinally to eveluate newborn screening for hypothyroidism. Of seventy-five children who had previously had their hearing tested, $15(20 \%)$ had hearing loss: 5 were conductive, 2 unilateral, and 3 bilateral; 9 sensorineural (1 unilateral, 8 bilateral; 1 child had bilateral sensorineural and conductive losses). The hearing loss was mild ( $21-40 \mathrm{~dB})$ in 10 cases, moderate ( $41-55 \mathrm{~dB})$ in 2 cases, and moderately severe (56-70 dB) in 3 cases. The children with hearing loss differed from the children without hearing loss in age treatment onset (22 vs 14 days) but not in disease severity or duration.

\subsection{Screening}

Screening is an all-encompassing term, which is defined as the preliminary acquisition of information for early detection of a condition. More specifically, screening is a process of applying certain rapid and simple tests and procedures to a generally large population to identify individuals with a high probability of having the target condition from individuals who probably do not have the disorder. Two important considerations are implicit in the above definitions: (1) screening is an issue of likelihood probabilities rather than a certainty of accuracy - the identification of persons who are likely to have the disorder from those who probably do not have the disorder and (2) screening must not be misconstrued into the totally separate issue of diagnosis. In short, individuals identified with a "positive outcome" during the screening procedure 
must be considered only "at risk" for the problem until careful diagnostic testing can determine accurately the presence or absence of the disorder.

\subsection{The need for an early hearing screening}

The first 3 years of life are the most important for speech and language acquisition. The issue of early versus late treatment for hearing impairment seems clear: the future of a child born with significant hearing impairment who is not identified and provided with appropriate intervention, has no way to acquire the fundamental language, social and cognitive skills required for later schooling and success in society. Language is essential to learning: the earlier intervention begins for youngsters with hearing impairment, the more likely they are to develop communication skills on par with their normal hearing peers.

Yoshinaga-Itano et. al (1998) compared the receptive and expressive language abilities of hard-of-hearing children whose hearing losses were identified by 6 months of age with the children whose hearing losses were identified after the age of 6 months. The language quotient (age equivalent of attained language skills divided by chronological age) of children with normal cognition (intelligent) was significantly better in the group that was identified early (mean $=91)$ than in the group that was identified later $($ mean $=70)$. This degree of difference was found at all ages at follow-up between 13 and 36 months and with all methods of communication (oral vs sign or combination). The difference between language quotients of the two groups was greater with more severe hearing loss. Although the group that was identified later had a lower cognitive quotient ( 88 in the early vs 76 in the later group), the difference 
in language quotient persisted when the children were stratified by cognitive quotient. This suggested that early identification and intervention was responsible for the higher language quotient in the group that was identified early. There was no difference in the language quotients in the subgroups of children who were identified later ( 6 to 12 months, 12 to 18 months, 18 to 24 months), which provides additional evidence that auditory stimulation in the first few months of life is critical for normal language development. Nikolopoulos et al. (1999) did a prospective study to assess the influence of age at implantation on speech perception and speech intelligibility following paediatric cochlear implantation. They found that the age at implantation is positively correlated with preimplantation assessment performance and with most of the outcome measures up to 24 months following implantation.

Animal studies show that early auditory deprivation interferes with the development of neural structures necessary for hearing. Mice deafened at birth show a marked decrease in the size of the cochlear nucleus. This change does not occur if the animals are deafened after hearing develops (7 days) and is reversible in gerbils if hearing is restored during the first week of life (Garganta \& Seashore, 2000). Human infants with hearing loss, particularly those with sensorineural impairments, may experience similar disruptions that will have a direct impact on language acquisition. Other factors can further exacerbate the consequences of hearing impairment. For example, some children have additional sensory disabilities and / or associated neurological disorders that further interfere with perceiving and processing information. Environmental factors, such as the quality of language input provided by the parents, can either facilitate or impede communication skills. Socioeconomic-related factors, 
such as the lack of access to the health care, other associated health problems, high-risk populations and social stresses also may exacerbate the consequences of deficits.

\subsection{Limitations of current methods}

The need for the early identification of children with permanent childhood impairment has long been recognized. In the UK, the early work of the School Medical Service, and of the Ewings in Manchester led in the 1960s to a de facto national screening programme (Bamford et al., 1998)). This was configured around a "distraction test" screen performed by health visitors at 7-9 months, and a back up screen at school entry. Infant distraction test, if used properly can be highiy effective in identifying deafness in infancy. By the early 1980 s doubts were being expressed about the performance of the screen. These doubts led to notable efforts by some to improve IDT by better training, equipment and protocols. However, doubts remained, particularly as the limited data available indicated that for a large proportion of children the age of identification of congenital hearing impairment continued to be very late (Bamford et al., 1998). Currently, the average age of detection of significant hearing loss in US is 14 months. Even when such a test is sensitive, however, the age at which a hearing aid is fitted is often delayed until after the first year of life (White et al., 1994). The limitations of the present organizational arrangements to meet perceived operational requirements at a reasonable cost are also well recognized. 


\subsection{History of infant hearing screening}

The origins of newborn hearing screening can be traced to Sweden. In 1956, Wedenberg reported that the most easily observable response of an infant to sound is the auro-palpebral reflex. He performed hearing test on 20 infants, between 1 and 20 days of age, to pure tone stimulus presentations at 105 to 115 dB SPL. In 1960, Carl-Axel Froding of Eskilstuna, Sweden evaluated the hearing of 2,000 newborns using a small gong and mallet, which produced a sound of $126-133 \mathrm{~dB}$ SPL. His technique was to observe the auro-palpebral reflex in quiet or sleeping infants.

The initial study of newborn hearing screening in the United States came from a research project conducted by Marion Downs, an audiologist, and Graham Sterrit, a Psychologist. In 1964, Downs and Sterrit teamed to conduct a city-wide project in Denver, Colorado to test all the babies born during a 1-year period. Using trained volunteers, and a specially designed, hand-held, batteryoperated infant hearing "screener" with a sudden onset stimulus of $90 \mathrm{~dB}$ SPL, more than 17,000 newborns were evaluated. However, the researchers' review of their data raised questions concerning the reliability and validity of the screening based on subjective behavioural observation.

The lack of confidence in behaviourally based mass infant hearing screening led recommendation the use of high-risk factors to identify infants at risk for deafness. They argued that, if the majority of deaf babies could be identified through a high-risk register system, there would be no need for hearing screening of the entire newborn population. 
In 1972, Joint Committee on Infant Hearing listed five high-risk alerting factors for congenital deafness:

1. History of hereditary childhood hearing impairment.

2. Rubella or other nonbacterial intrauterine fetal infection (e.g., cytomegalovirus or herpes infection).

3. Defect of the ear, nose or throat; malformed, low-set, or absent pinnae; cleft lip or palate (including submucous cleft); any residual abnormality of the otorhinolaryngeal system.

4. Birth weight less than 1500 grams.

5. Bilirubin level greater than $20 \mathrm{mg} / 100 \mathrm{ml}$ serum.

Also during the 1970 s, considerable work was being conducted by a number of auditory researchers to develop objective, physiologically based hearing screening techniques, which could replace the widely used subjective behavioural observation of infant responses to acoustic stimuli. Two techniques, the Crib-O-Gram and Auditory Brainstem Response Audiometry had been found to be helpful.

In 1982, Joint Committee on Infant Hearing expanded the risk criteria to seven factors. The two additional risk factors that were added to the list were bacterial meningitis caused by Haemophilus influenza and severe asphyxia demonstrated by Apgar scores has 3 or lower. The committee recommended that the infants should be screened, under supervision of an audiologist, prior to 3 months of age, but no later than 6 months after birth.

In 1990, The Joint Committee on Infant Hearing met again. The committee recommended that the hearing screening was to be completed prior to the atrisk baby's discharge from the hospital, but no later than 3 months of age. 
Further, it stated that, because of the high false- positive and false-negative results related to behavioural observation screening, that the initial hearing screening should be based on the auditory brainstem response (ABR) test. With concern that the $A B R$ technique could result in some false-positive results, ongoing assessment and observation of the infant's auditory behaviour was recommended during the early intervention stages. The committee increased the risk criteria to ten factors. Ototoxic medications, prolonged mechanical ventilation and stigmata or findings associated with a syndrome known to include sensorineural hearing loss were added to the list.

The National Institute on Deafness and Other Communication Disorders (NIDCD) sponsored a Consensus Development Conference on Early Identification of Hearing Impairment in Infants and Young Children early in 1993. The NIDCD Consensus panel identified the main risk factors for hearing impairment as bacterial meningitis, severe head trauma, viral encephalitis or labyrinthitis, excessive noise exposure, exposure to ototoxic drugs, congenital CMV infection, familial hearing impairment, infants with chronic lung disease or diuretic therapy, and infants with repeated episodes of otitis media with persistent middle ear effusion. The panel concluded that the high-risk register approach to infant screening actually misses $50 \%$ of children who are eventually diagnosed with hearing impairment. Based on this fact, the expert panel developed a consensus statement recommending that universal hearing screening be implemented. It was recommended that the screening be conducted with a two-stage protocol consisting of evoked otoacoustic emissions testing (EOAE) for all infants followed by auditory brainstem response (ABR) screening for infants who fail the EOAE screening. The first stage of screening 
with otoacoustic emissions was recommended to identify babies with normal hearing in the most cost-effective manner. The ABR second stage screening was recommended to confirm the accuracy of the EOAE screening and to serve as a mechanism for accurately referring the appropriate babies for further follow-up diagnostic hearing testing.

In 1994, The Joint Committee on Infant Hearing endorsed the goal of universal detection of all infants with hearing loss as early as possible. The Joint Committee agreed that all newborns with hearing loss should be identified before 3 months of age, and all hearing impaired infants should be involved in intervention by 6 months of age. The statement does not recommend any specific screening technique or program protocol, per se, but recognizes that infant hearing program protocols will likely vary by regional location, individual needs, and administrative structure.

After a meeting that has been conducted on 15-16 May 1998 in Milan, a European Consensus Statement on Neonatal Hearing Screening was produced. The statement says that neonatal hearing screening should be considered to be the first part of a programme of habilitation of hearing impaired children. The methods for identification of permanent childhood hearing impairment $(\mathrm{PCHI})$ in the neonatal stage are effective and can be expected to identify at least $80 \%$ of cases of PCHI whilst incorrectly failing $2-3 \%$ of normally hearing babies in well-controlled programmes. Neonatal testing in maternity hospitals is more effective and less expensive than behavioural screening conventionally carried out at 7-9 months. Targeting neonatal testing on only 6$8 \%$ of babies at risk of $\mathrm{PCHI}$ reduces cost but cannot identify more than $40-50 \%$ of cases. 